\title{
ACRL candidates for 1995 elections
}

Be sure to vote in the election this spring

$\mathbf{T}$ he listing for each of the candidates includes their title and institution.

\section{Vice-President/President-Elect}

Bessie K. Hahn, University Librarian, Brandeis University; William Miller, Director of Libraries, Florida Atlantic University.

\section{Board of Directors}

Director-at-Large: Carol M. Pfeiffer, Associate University Librarian, University of Virginia; Aline Soules, Director, Kresge Business Administration Library, University of Michigan.

Director-at-Large: Linda S. Muroi, Library Instruction Coordinator \& Reference Librarian, San Diego State University; Stanton F. Biddle, Professor/Administrative Services Librarian, Baruch College, City University of New York.

\section{Afro-American Studies Librarians}

Vice-Chair/Chair-Elect: Rocbelle Redmond Ballard, Reference Librarian, University of Central Florida; Mary G. Wrighten, Multicultural Services Librarian, Bowling Green State University.

Secretary: Anita Grant, Head, Circulation De partment, Ohio University, Athens; Sylvia $Y$. Curtis, Associate Librarian (Black Studies and Dance), University of California, Santa Barbara.

\section{Anthropology and Sociology Section}

Vice-Chair/Chair-Elect: Fred J. Hay, Librarian, W. L. Eury Appalachian Collection, Appalachian State University; Janita A. Jobe, Government Publications Librarian, University of Nevada, Reno.

Secretary: /. Christina Smith, Anthropology/ Sociology Bibliographer, Boston University; Isabel del Carmen Quintana, Cataloging Librarian, Harvard University.

Member-at-Large: $A n n$ L. Wood, Reference Li- brarian, University of Massachusetts, Amherst; Lynne M. Schmelz, Librarian of the Tozzer Library, Harvard University.

\section{Arts Section}

Vice-Chair/Chair-Elect: Nancy L. Stokes, Performing Arts Bibliographer, University of Akron.

Secretary: Roland C. Hansen, Readers' Services Librarian, The School of the Art Institute of Chicago; Kimberly Hale, Acquisitions/Serials Librarian, Columbia College, Chicago.

\section{Asian, African and Middle Eastern Section}

Vice-Chair/Chair-Elect: David L. Easterbrook, Curator, Melville J. Herskovits Library of African Studies, Northwestern University; David Nelson, Head, Cataloging, Texas A\&M University.

Secretary: Clare B. Dunkle, Monographs Cataloger, Trinity University; Gregory A. Finnegan, Humanities and Social Sciences Reference-Bibliographer, Dartmouth College.

Member-at-Large: Jobn A. Eilts, Library Services Officer/Middle East Specialist, The Research Libraries Group, Inc; Karl Kabler, East Asian Bibliographer and Head of East Asian Technical Services, University of Pennsylvania.

\section{Bibliographic Instruction Section} Vice-Chair/Chair-Elect: Loanne L. Snavely, Head, Arts Library, Pennsylvania State University; Elizabeth Park, Acting Head, Reference Department, University of Memphis.

Secretary: Susan G. Miller, New Haven, Connecticut; Diane $M$. Zabel, Social Science Reference Librarian, Pennsylvania State University.

Member-at-I arge: Craig Gibson, Head, Library User Education, Washington State University Library; Alphonse N. Vinh, Reference Librarian, University of the South.

\section{College Libraries Section}

Vice-Chair/Chair-Elect: Pamela Snelson, Assistant Director for Automation and Public Ser- 
vices, Drew University; Elizabeth W. Kaschins, Senior Reference Librarian and Professor, Luther College.

Secretary: Eugene S. Mitchell, Director of Ljbrary Services, Alvernia College; Peter V. Deekle, College Librarian, Wheaton College.

Member-at-Large: Jonathan D. Lawer, Director, Murray Learning Resources Center, Messiah College; Catherine M. Rod, Associate Librarian, Grinnell College.

\section{Community and Junior College Libraries Section}

Vice-Chair/Chair-Elect: Douglas K. Lebman, Director, Library Technical Services, MiamiDade Community College; Alice Beverley Gass, Dean of Learning Resources, Guilford Technical Community College.

Secretary: MaryAnn Laun, Technical Services Librarian, Pasadena City College; Mary Dolven, Director of Library Services, Diablo Valley College.

\section{Education and Behavioral Sciences Section}

Vice-Chair/Chair-Elect: Allison G. Kaplan, Cataloger, Education Resource Center, and Coordinator of the School Library Media Specialist Program, University of Delaware, Newark; Mary Beth Minick, Coordinator of Reference Services and Education Librarian, Indiana University-Purdue University at Indianapolis.

Secretary: Rolland H. McGiverin, Head, Teaching Materials, Microforms, and Media Department, Indiana State University; Mary M. Gilles, Business Subject Specialist, Washington State University.

Member-at-Large: Gail F. Latta, Psychology/ Sociology Subject Specialist and Liaison Librarian, University of Nebraska-Lincoln; Margaret $K$. Cook, Reference Librarian, West Virginia University.

\section{English and American Literature Section}

Vice-Chair/Chair-Elect: Charles Perry Willett, Subject Specialist for English and American Literature, Comparative Literature, Theater and Drama, and Philosophy, Indiana University.

Secretary: Betty H. Day, Humanities Bibliographer, University of Maryland at College Park; Robert W. Melton, Publications Coordinator and Bibliographer for English, American and Comparative Literature, Film, Theater and Communication Studies, University of Kansas.
Member-at-Large: Susanna Bartmann Pathak, Resource Services Librarian for English, German, Comparative Literatures \& Film Studies, and Coordinator, Electronic Text \& Imaging Center, Johns Hopkins University; William A. Wortman, Humanities Librarian, Miami University, Ohio.

\section{Extended Campus Library Services Section}

Vice-Chair/Chair-Elect: Thomas E. Abbott, Dean of Learning Resources and University Development, University of Maine at Augusta; Mem Catania, Librarian, University of Central Florida, Brevard Campus.

Secretary: Jack E. Fritts, Assistant University Librarian for Public Services and Automation, National-Louis University; Anne M. Casey, OffCampus Librarian, Central Michigan University. Member-at-Large: Ann Taylor Blauer, Head of Informational Services, Baldwin County, University of South Alabama; Robert G. Murdoch, Associate Director for Public \& Technical Services, Utah State University.

\section{Law and Political Science Section}

Vice-Chair/Chair-Elect: Catherine Doyle, Access Services Librarian, Christopher Newport University.

Secretary: Brian B. Carpenter, Patent Librarian, Documents/Microtext Reference, Texas A\&M University.

Member-at-Large: Laura M. Bartolo, Information Services Librarian, Kent State University.

\section{Rare Books and Manuscripts (RBMS)}

Vice-Chair/Chair-Elect: NoraJ. Quinlan, Rare Book Cataloger, University of Miami; Susan $M$. Allen, Director of Libraries and Media Services, Kalamazoo College.

Secretary: Stephen R. Tabor, Senior Bibliographer, ESTC, University of California, Riverside; Deborah J. Leslie, Rare Book/Systems Librarian, Library Company of Philadelphia.

Member-at-Large: Elaine B. Smyth, Head, Rare Book Collections, Louisiana State University; Henry F. Raine, Head of Technical Services/ System Manager, Folger Shakespeare Library.

\section{Science and Technology Section}

Vice-Chair/Chair-Elect: Julia Zimmerman, Associate Director for Operations, Georgia Institute of Technology; Amy L. Paster, Life Sciences Reference Librarian/Science Cataloger, Pennsylvania State University. 
Secretary: Mary J. Markland, Head of Reference, University of Massachusetts Medical Center; Sara Shatford Layne, Head, Cataloging Division, Science \& Engineering Library, University of California, Los Angeles.

\section{Slavic and East European Section}

Vice-Chair/Chair-Elect: Catby M. Zeljak, Reference Librarian/Slavic, East European, and East Asian Subject Specialist, George Washington University; Allan Urbanic, Librarian for Slavic Collections, University of California, Berkeley. Member-at-Large: Joanna K. Dyla, Slavic Cata$\log$ Librarian, University of California, Berkeley; Alena L. Aissing, Germanic and Slavic Studies Librarian, University of Florida.

\section{University Libraries Section}

Vice-Chair/Chair-Elect: Donald G. Frank, Head of the Cabot Science Library and Coordinator of Science/Technology Libraries, Harvard University; Kent H. Hendrickson, Dean of Libraries, University of Nebraska-Lincoln.

Secretary: Mary H. Munroe, Head, Collection Development Department, Georgia State University; Karen Williams, Social Sciences Team Leader, University of Arizona.

Director-at-Large: James A. Estrada, Director, H.B. Trecker Library and Assistant Director for Regional Campus Libraries, University of Connecticut; Jobn M. Haar, Assistant Director for Collections, Central and Science Libraries, Vanderbilt University.

Director-at-Large: Emma B. Perry, Dean of Libraries, Southern University; Birdie O. Weir, Director, J. F. Drake Memorial Learning Resources Center, Alabama A\&M University.

\section{Western European Specialists Section}

Vice-Chair/Chair-Elect: Diana A. Chlebek, Associate Professor of Bibliography in Fine Arts, Languages, and Literature, University of Akron; Kurt F. De Belder, Assistant Curator, Western European Literatures \& Languages, New York University.

Secretary: Gail Hueting, Assistant Modern Languages Librarian, University of Illinois at Urbana-Champaign; Fred W. Jenkins, Catalogue Specialist/Rare Book Librarian, University of Dayton.

Member-at-Large: Charles D. Spornick, Chief Coordinator, Collection Management, Emory University; Julie Still, User Education Librarian, Trenton State College.

(Candidates cont. on page 742)

\section{(Policy cont. from page 730)}

nected with the work of other very different, even remote, groups of people. Staff learned about the issues of other departments and divisions and hegan to see the interconnectedness-often invisible - that exists in the library. The process of taking the draft policy to other divisions and departments fed the knowledge loop in both directions and the policy became stronger (and more sensible!) because of wide participation and discussion.

The final draft, reviewed by the Administrative Committee and the Management Councilwhich consists of all the department heads, the AULs, and the university librarian-has been added to the Policies and Procedures Manual to serve as a guideline for the borrowing staff and service staff throughout the library. Review by bodies at higher levels helped to ensure that this policy is consistent with other service policies in the library and revealed the work of the Interlibrary Loan Department to some who had little contact with it.

\section{It's that way because...}

The experience of articulating, formulating, and setting policy with the staff called upon to implement it was refreshing both because of the energetic contributions of the staff and because it allowed us to work together and with many other staff members in the library. The resulting policy is more meaningful because it was built in this way and certainly has the enthusiastic support of those who will use it.

Beyond that, staff was, to use a hackneyed but valuable word, empowered by the experience of crafting a significant, librarywide document. Their opinions were very important-1 would say crucial-to the building of a practical and coherent policy. The importance their opinions were accorded was shown by the AUL for public services and by the interest the document generated in other departments and divisions. Many in the library, possibly for the first time, saw the work of this group.

As a consequence, staff members take a great deal of pride in the policy and feel that they do matter and that their opinions count enough to affect formal library policy. Clearly, there are some types of policies that cannot and should not be written with the wide participation that this experience suggests, but I am certain that, more often than not, more policies can and should include the expertise and opinion of paraprofessional staff members. 


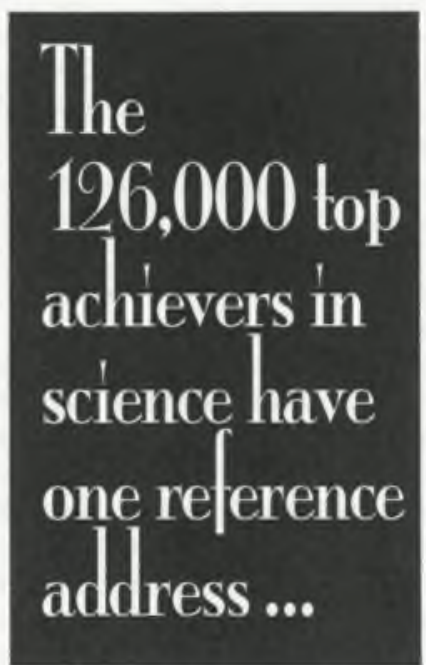

\section{American Men and Women of Science 1995-96 19th Edition}

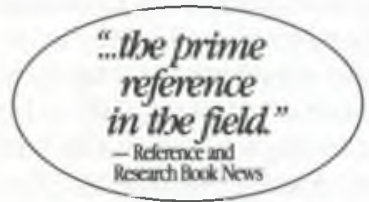

\section{From R.R. Bowker}

Here's exciting news! The about-to-bepublished 19th edition of AMWS will have the latest background details on over 126,000 top members of the American and Canadian scientific communities who've made their mark on everything from chemistry and medicine to physics and astronomy.

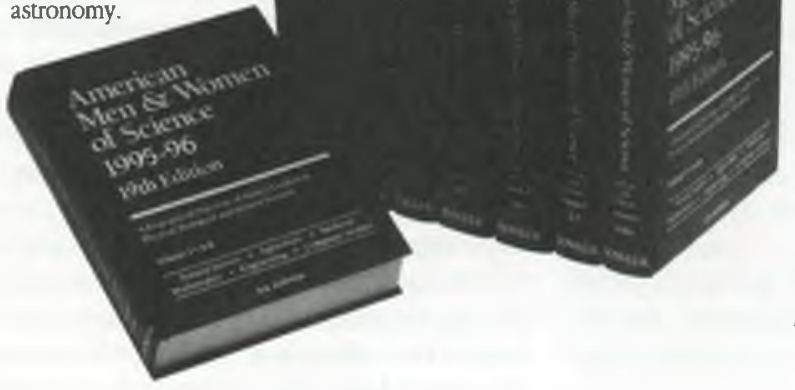

superconductors by state, or by province. Once you have entrants' names, you have their biographical details in the main listing.

Unbeatable references and recommendations! Here's the top talent pool to staff a project, conduct research, address a meeting, author an article or book, or teach a course or seminar.

Big savings if you act now: Save $\$ 140.00$ when you place a prepublication standing order! Place AMWS on standing order before November 30, 1994, and save $\$ 140.00$ off the $\$ 850.00$ list price. Your final price is $\$ 710.00$. You'll always have the latest edition on hand because you'll automatically receive future editions - at a 5\% discount. Guaranteed satisfaction. Examine your copy of AMWS for 30 days - if you're not completely satisfied, just return it and receive a full refund.

The reference source that scientists themselues use is essential for researchers, recruiters, government personnel, academic administrators, scientists, and the librarians who work with them.

\section{To order, call} $1-800-591-8110$.

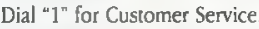
and ask for Dept. "FFD"

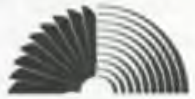

R.R.BOWKER A Reed Reference Publishing Company 121 Chanlon Road New Providence, NJ 07974 